\title{
Mobilizing followers in the Spanish transition to democracy: Adolfo Suárez and Felipe González
}

\author{
Manuela Ortega-Ruiz and Francisco Javier Luque-Castillo \\ University of Granada, Spain
}

This article tries to demonstrate the power of discourses to promote followers' self-esteem and self-worth. Following Shamir et al. $(1993 ;$ 1994), promoting those feelings, followers refuse their individual goals in favor of a collective one. This action provides an unconditional commitment to the leader's proposals, and may pave the way for the leader. To get that objective, we analyse the Spanish case at two key moments: the Transition to democracy and the current crisis. The study of a society at two different times sheds light on the study of leadership and, more specifically, on the relationship between leaders and their followers. The methodology is qualitative, using the discourse analysis to identify those elements that Shamir et al. considered fundamental to the enhancement of self-esteem and self-worth: personal effort, faith in a better future, and past and present values, among others.

Keywords: self-concept, self-esteem, self-worth, transformational, Transition

\section{INTRODUCTION}

The main objective of this article is to explore the communication strategies that two leaders of the Spanish Transition to democracy carried out to mobilize citizens in support of their proposals. Unveiling these strategies will allow us to establish models for comparison with other periods of Spanish history or with that of other neighboring countries, as well as clarifying the importance of leaders for political change, especially concerning the processes of democratic transition that took place in Europe during the last decades of the twentieth century. It is true that the works of O'Brien (2007) and Zúquete (2011) shed light on the transitional leaders, but they did not focus on their communication skills. However, this issue has been tackled by authors concerned with the analysis of communication methods, such as rhetoric or metaphors (Goatley 1997; Charteris-Black 2012; 2007). We agree with these scholars that, for the leader, communication is not only an essential instrument, as it helps him to transmit to followers his vision of the future - an element that gained importance in the 'New Leadership school' - but can also explain his success or failure during periods of political uncertainty. This article aims to be coherent with such a scholarly tradition, featuring its multidisciplinary approach to the leadership process.

Thus, following the contributions of Shamir et al. (1993), the fundamental hypothesis is that, in times of political or economic instability in Spain, leaders who achieved greater support for their proposals tended to base their communication strategy on the 
fostering of their followers' self-concept. Such promotion was undertaken through the encouragement of self-esteem and self-worth, appealing to feelings of collective identity and envisioning desires for a better future. This communication strategy, reflected in their speeches, was reinforced by the behavior and the image of the leaders, whose actions were consistent with their words.

In regard to such premises, we have developed a research intended to prove the validity of the aforementioned hypothesis, through the analysis of two cases selected from the Spanish Transition to democracy: Adolfo Suárez and Felipe González.

\section{TRANSFORMATIONAL LEADERSHIP THROUGH DISCOURSES}

Leadership is a concept that helps to explain many political phenomena, given the personalized nature of politics nowadays. To a great extent this is a consequence of the importance gained by mass media - particularly television - in our daily lives, as they used to focus on persons rather than organizations when tackling politics (McAllister 1996; 2007). Concerning the Spanish Transition to democracy, personalization of politics obviously had to do with such phenomena, even if it was in an incipient way, but it must be stressed that the most important elements of the new democratic constitution were agreed by the leaders of the main political parties in informal meetings, which took place in cafeterias, bars, and private houses or individual offices - something later theorized as the 'elite settlement' model of transition to democracy (Gunther et al. 1995, p. 20). For this reason, it would be a mistake to try to understand Spain's democratic transformation without taking into account the role played by leaders. Jean Blondel (1987, pp. 2-3) defined political leadership as 'the ability of the one or few who are at the top to make others do a number of things (positively or negatively) that they would not, or at least might not, have done.' To explain such influence, Blondel pointed out several factors such as the leaders' personal traits, their institutional position, or the characteristics of the context. Howard J. Elcock (2001, p. 48) emphasized other elements of the political leadership process, such as the relevance of national laws and the characteristics of society on the one hand, and the personality of the leaders, their origins, and their education, on the other.

It is generally accepted that political leadership is a process by which one person, normally in a relevant political position - formal or not - influences others, the followers, to accomplish an objective or political project. In this sense, political leadership is always a social process of adaptation and innovation to the environment, where the leader and the followers are involved (Masciulli et al. 2009, p. 7). Context, therefore, defines the leader's tasks and behavior, appearing to have several types of leadership based on it. According to this, James M. Burns (1978) distinguished between transformational and transactional leadership. ${ }^{1}$ The first arises in times of change, a period in which a person appeals to great ideas for mobilizing people in achieving their goals. Transformational leadership is based on the profound relationship between the leader and his followers, involving the followers in a project that the leader has defined together with them. This relationship demands great motivation levels from

1. Burns elaborated a complete definition about leadership, not only in a political situation, but in an organizational context: 'Leadership over human beings is exercised when persons with certain motives and purposes mobilize, in competition or conflict with others, institutional, political, psychological, and other resources so as to arouse, engage, and satisfy the motives of followers' (Burns 1978, p. 18). 
both the leader and his followers to accomplish the established objectives (ibid., p. 20). This type of leadership refers to the fundamental values of a society, ${ }^{2}$ as the transformational leader defines and maintains these values over time. In fact, this kind of leader changes the basic structure of the system of values and beliefs in which they act, even creating a new one that replaces the previously existing one. But the nature of change, and not simply the degree, is the most important effect (Burns 2003, p. 25). Therefore, the performance of the leader is not limited to a simple variation of the system, but it implies a transformation of the basic rules of social behavior in the leader's society. Transactional leadership, by contrast, is based on the exchange of things of value, and is frequent during periods of political stability (Burns 1978, p. 19).

One aspect that stands out in transformational leaders is their ability to engage followers in their projects. Empowerment means that followers are not mere spectators but they participate in the process of leadership. The leader drives them to act, in what can be also considered a bottom-up relationship, because the followers communicate their ideas, beliefs, and concerns to the leader, who incorporates them into the project or even the ideology. Empowerment is the element that makes this leadership a participative and democratic one. But there are other elements that differentiate transformational leaders from others. These include the symbols that the leader uses, as well as the fact that the leader satisfies the followers' psychological needs (Burns 2003, p. 26). Bernard Bass, for his part, has classified the qualities of these leaders into four categories (Bass 1998, pp. 5-6). First, charisma or the leader's idealized influence, a term that was coined by Weber in his study about authority. Followers attribute to the leader supernatural traits and power, and perceive her/him as a role model, considering her/him as trusted, admired, and respected (Weber 1993, p. 193). Thus, transformational leaders have to respond to this definition, which leads them to behave ethically and morally. Regarding communication, charisma helps to create an intense emotional relationship using symbols, imagery, and persuasive language (Antonakis 2012). The second category conceived by Bass is inspirational motivation. Leaders motivate and inspire their followers to achieve the proposed change, involving them in the designed vision. The third is intellectual stimulation. Leaders encourage followers to be innovative and creative in solving problems and creating alternatives. Finally, Bass underlines individualized consideration. Interaction between leaders and followers is personalized, so followers perceive that their proposals are taken into account by leaders.

Transformational leadership, in consequence, appears in periods of political change, establishing the foundations of a new model that will be configured over time. Communication is considered essential in this class of leaders because, through his speeches, this type of leader persuades citizens that they can provide themselves with a better future. In this sense, the leader is 'someone who provides a sense of social purpose and motivates followers by providing explanations that correspond with unsatisfied needs' (Charteris-Black 2007, p. 7). The discourse is intended to increase the citizen's self-concept, understood as a set of perceptions, ideas, and opinions that allow individuals to describe themselves (Burns 1990), in order 'to succeed and overcome even the greatest obstacles in life' (Bong and Clark 1999, p. 139). Several elements could define self-concept, including competence judgment coupled with reactions and feeling of self-worth (Pajares 1996), or affective-cognitive structures about self-relevant experiences (Markus and Nurius 1986). In general terms, we can

2. For Burns, these values, defined as transformational, are the principles of order, freedom, equality, justice, and the pursuit of happiness. 
say that the self-concept is composed of self-esteem - sense of competence to control a given environment - and self-worth - moral sense or cultural qualities, related to the individual's behavior (Gecas 1982; Bandura 1986). In this regard, the self-concept is based on individual and social identities, which are also arranged hierarchically. And these identities are affected by hope for a better future, which makes possible the mobilization of people, as well as the act of giving up their own wishes and desires in favor of a collective future project.

Assuming these premises and following the contributions of Shamir et al., transformational leaders introduce in their messages references to values and moral justifications, they appeal to collective identity, link the present with thew past and future, esteem followers' worth and their individual and collective capacity, express their expectations in them, and make reference to long-term goals. Likewise, their speeches are presented as coherent with their behavior, appearing as role models whose ideas and way of life fit perfectly with the values of society (Shamir et al. 1993, pp. 584-586; Shamir et al. 1994, p. 29). Communication, therefore and as stated above, is essential for transformational leadership, and we must analyse both the substance and the form. The form influences the way followers perceive the leader, and that is why we consider that their behavior is an important element to be examined. But it is the substance that causes a greater commitment between leaders and followers (Davis and Gardner 2012, p. 919). Also, although the nonverbal elements are important, they produce only short-term effects, while the content of the speech is what endures over time and promotes the followers' actions.

\section{METHODOLOGY}

In this study, we focus on the discourse as an expression of leaders' behavior as well as being the means by which leaders get their acts and values recognized as belonging to the whole society. Discourses can be defined as a system of thought composed of ideas, attitudes, actions, beliefs, and practices of people and the world in which they live, as well as being a social process of legitimation through the construction of truths and their relationship with power (Foucault 1972, pp. 12-13). From this idea, theories about discourse analysis accept that language constructs realities, influencing the society (Lessa 2006, pp. 285-286; Wodak and Meyer 2009, p. 5). In this sense, discourses can legitimize the status quo while, by contrast, laying the groundwork for change (Chouliaraki and Fairclough 1999). Therefore, we have to analyse the structure of the discourse, how it works in society and how it changes over time, in order to understand its impact among the citizens. Thus, using discourse analysis, we study not only the content of speech, but also the interaction with the public, because, following Flowerdew's (2014, p. 2) ideas, 'discourse analysis is concerned with the interpretation of texts and an important part of this analysis is how texts are related to the contexts in which they are produced and received.'

We have used different sources to obtain the discourses studied in order to verify our hypothesis. First, the digital archives of two newspapers: El País and $A B C$, as well as the digital archive of Radio Televisión Española (Spanish public radio and television). In addition to the González speeches, we have consulted the official magazine of the Socialist Party, which contained the major speeches of their leaders. These sources have been very useful for collecting electoral speeches, as well as relevant discourses at given times, such as press appearances or meetings with a particular group, such as intellectuals or businessmen. Apart from these sources, we have resorted to the digital 
archives of the Congreso de los Diputados (House of Representatives). We have studied not only the content but also the reactions of the media. We have focused on editorials and columnists' main articles, including the opinions expressed in the newspapers, by both followers that had attended leaders' speeches, and party colleagues or political rivals. During the Transition, the mass media played a relevant role in presenting the new leaders and parties in Spain, spreading their messages and projects for a better future. Although the press was the most important of the media, television completed the message of the leaders, especially regarding nonverbal communication. For these reasons, we have analysed their discourses both in the press and on television.

In carrying out this research, we have analysed the speeches of two leaders, Adolfo Suárez and Felipe González, who were relevant in the Spanish Transition to democracy, that is, between November 1975 (the date of the death of Franco) and October 1982 (when the socialist party won the elections). ${ }^{3}$ The selected discourses contain more than 500 words and they took place in several contexts. In total, we examined 23 of Suárez's discourses, of which eight were broadcast on television, three had an electoral nature, and the rest corresponded to parliamentary interventions. Regarding Felipe González, we analysed 87 discourses, of which 55 were electoral and political meetings, 22 were statements at Parliament, four were discourses in the Socialist Party Conferences, and six were on television. ${ }^{4}$ Suárez, President of Government - Prime Minister - from 1976 to 1981, gave fewer conferences or meetings than Felipe González, the main opposition leader and head of the Socialist Party. Nevertheless, Suárez often appeared on TV because he was aware of the power of the image in modern societies. Although Felipe González appeared less frequently on television, his interventions in party meetings or electoral events were usually broadcast, making it possible for him to transmit his message directly to the citizens, the same as Suárez. ${ }^{5}$

The findings presented below were made after developing a qualitative approach, based on the study and identification of the categories devised by Shamir et al. (1994, pp. 31-36), to analyse Jesse Jackson's speech at the US Democratic Convention of 1988, following the aforementioned ideas; and the research of Davis and Gardner (2012), who studied the presidential leadership in crisis contexts. Following their contributions, we have organized the discourses into five categories:

1. References to collective history and to the continuity between the past and the present, and even the future. These types of references reinforce the importance of the collective identity and link the past with the objectives of future, creating an 'evolutionary sense' that contributes to increasing the actions and objectives

3. Formally, the Transition to democracy ended when the Constitution was approved, in December 1978. However, and following Cotarelo, the new system arguably was not consolidated until October 1982, or even until June 1986, when the Socialist Party won for the second time (Cotarelo 1992). These two periods were defined by Mario Caciagli (1986) as 'Institutional Transition' (from Franco's death until the Constitution), and 'Political Transition' (from the approval of the Constitution until the socialists' electoral triumph).

4. The discourses have been analysed in the original language, Spanish. We have translated some paragraphs to highlight our propositions, although the words can lose their meaning in the process. We have tried to preserve their original ideas, however.

5. During the Transition, there were only two TV channels, both of them public, implying that there were not many opportunities to appear on this medium. For this reason, Felipe González accepted almost all interviews and he often called a press conference to access television. 
of the followers (Shamir et al. 1994, p. 31). On this issue, we have looked for references to the Spanish past, whether at a specific period - the Second Republic (1931-1939) or Franco's dictatorship (1938-1975) - or as a specific historical event - party foundation or death of a political personality. Also, we have considered the references to past personalities invoked to reinforce their arguments.

2. References to the community and to collective identity. Leaders appeal to the collective identity to increase the importance of that identity for reinforcing the followers' self-concept and to link the goals for the future with the effort that has to be made to reach them (Shamir et al. 1994, p. 32). Such a course of action is in fact an expression of the 'natural' inclination of 'speakers of the same language' to 'seek their own political identity' (Billing 2004, p. 13). References to the collective can be based on metaphors, which can be very useful when references to moral or emotional words are threatened by imbalance (Charteris-Black 2004, p. 21). Following Davis and Gardner (2012, p. 929), we have been seeking references to Spain, to community or to a united society. This section is very much connected with the previous one, because the leaders used references to the past to intensify the collective vision of their projects.

3. References to the efficacy of collective effort. This category is related to the fact that leaders promote collective effort to achieve their objectives or their visions of the future, appealing to the union between the followers (Shamir et al. 1994, p. 33). To identify these references, we have indicated when leaders appeal to unity to achieve their final goals. Likewise, we have taken into account the moments in which they express their confidence in their followers to pursue such aims, and when they ask for the effort to be maintained to achieve a better future. Appealing to the efficacy of collective effort, leaders empower followers.

4. References to a leader's similarity to and identification with their followers. ${ }^{6}$ Leaders try to demonstrate that they are part of the same community as the followers. But they are not merely one more member, they want to be a representative of that community and a role model. Thereby, leaders promote their own beliefs, values and moral justifications, making it easier for the followers to accept the leader's project (Shamir et al. 1994, p. 34). In this sense, identification with the followers promotes their self-concept, because they want to be the same as the leader and the leader encourages it. We have indicated when leaders refer to biography to reinforce their proposals. Thus, the leaders use the first person plural, assimilating themselves with their followers in the tackling of everyday problems, thus favoring the latter's identification with the former (Davis and Gardner 2012, p. 925).

5. References to a better future. Followers' self-esteem depends on the vision of the leader (House and Shamir 1993, p. 86). People can be motivated by faith in a better future, because the feeling of wishful thinking and hope is inherently pleasant (Shamir et al. 1994, p. 36). We have looked for references to the leader's project of the future. In doing that, we have indicated when leaders mention concepts such as hope, faith, tomorrow, dreams, trust, or the future.

6. In this category, we have introduced the references to values and moral justifications that Shamir et al. consider a different category. We have linked these categories because we consider that the values and moral justifications are part of the leaders' thought and that they express it through their images and beliefs. 


\section{THE DISCOURSES OF CHANGE: A NEW GENERATION AT THE HELM OF SPAIN}

In the early stages of the Transition, both Adolfo Suárez and Felipe González appealed to the citizens to consolidate their political position. However, in the case of Adolfo Suárez, his behavior was strongly linked to his role as President of the Government, and therefore his interventions were limited to official acts, such as media appearances or speeches in Parliament. Meanwhile, González became more visible, organizing multitudinous conferences and meetings with the citizens. In addition, his participation in public meetings attracted a significant number of Spaniards, gaining great popularity among them.

\subsection{Adolfo Suárez: the innovative president}

The appointment of Suárez as President of Government surprised everyone. Although he had held political positions in the previous regime, Suárez was not as widely known among the people as other members of past dictatorship governments such as Manuel Fraga or José María Areilza. However, this fact favored him because his image was not clearly associated with Franco by the opposition and, at the same time, did not raise suspicion among the relentless supporters of the old regime. He was appointed by the King on July 1976, and given the responsibility of passing a law that allowed the holding of free elections, as well as the adoption of a democratic Constitution. The first democratic elections took place in June 1977, and were won by Suárez's coalition, the Unión de Centro Democrático (UCD, the centerist party). This coalition functioned as his political springboard, but it was also the origin of his decline as a politician, given that soon he had to face opposition within his own party. During that period, the new Constitution received the support of the majority of political parties and the majority of the population. ${ }^{7}$ And some months later, general elections were held again and Suárez was confirmed in his position. But thereafter, Suárez went into decline, losing the support of citizens progressively.

Before analysing the speeches of Suárez, it is necessary to emphasize that the president opted for television to transmit his message. Adolfo Suárez knew this medium perfectly because he was the general director in TVE between 1969 and 1973, and his old friends in public television continued helping him when he became prime minister. ${ }^{8}$ Through this medium, the message could reach more people. In fact, his first public speech was a TV recording broadcast after his presidential appointment, like the other most important speeches of his political career. Now, we analyse five of them, given between 1976 and 1979 and broadcast directly to the Spaniards.

7. Constitution was passed in Congreso de los Diputados (the Lower House) with the following results: 325 votes in favor, 6 against, 14 abstentions, and 5 absences. On the same day, Constitution was passed in Senate (the Upper House), with a similar result: 226 votes in favor, 5 against, 8 abstentions, and 9 absences (see Journal of Sessions of the Congreso, no 130, October 31, 1978). The referendum was held on December 6, 1978, with the following results: participation was 67.11 percent, of which 88.54 percent voted in favor and 7.89 percent against (the remaining 3.57 percent being invalid, blank, or null votes).

8. Until the late 1980s and early 1990s, TVE was the only channel in Spain, giving him an important platform to make himself known among Spaniards. 
1. References to collective history and to the continuity between the past and the present, and even the future. Suárez did not appeal frequently to history, owing to the special circumstances of the Transition. References to earlier times, such as the Republic, could cause suspicion among Franco elites, especially the military who were still active during the Transition. And references to Francoism could cause suspicion among the democratic opposition members. In this sense, although Suárez never defined the past as glorious, he mentioned a tradition in which to base the reforms of his government:

Spanish political behavior meets current exigencies. This does not mean, at all, that we ignore our immediate past. It means that we face it but we face it responsibly. It means we accept its heritage, but we accept it with the request of perfecting it and adjusting it - as any of us would do in their houses - to the current demands of the great national family. ${ }^{9}$

Also, in this same speech, he wanted to emphasize the courage of Spaniards in facing the change process with responsibility, as they had done in the past: 'Spain has a reason to be proud: proud of a people who always, and especially during the last year, showed an exceptional sense of responsibility.'

2. References to the community and to collective identity. One of the tools he used on numerous occasions was the appeal to collective identity. In his first public speech, he presented himself as the new president whose main mission was the establishment of democracy in Spain. To do that, he appealed to the collective identity, mentioning repeatedly the word 'Spain' as well as the need to build a new country:

If Spanish society aspires to normal democracy, we will try to get it. If political reform has been started as an urgent task, we will accelerate with the realism that our time demands. And if we find serious problems in our daily lives, we will strive to find solutions. ${ }^{10}$

3. References to the efficacy of collective effort. Effort and work, therefore, were qualities that Suárez attributed to the Spaniards, and to emphasize them, he urged them to achieve the objectives, thus involving them in the common project. The union of the citizens appears as a crucial condition for the rebuilding of the country: 'All together, we are going to make the effort of rebuilding Spain.' 11 It was not a task only for him, nor his party or the government, but it was a challenge for the entire country. A reference to the unity of the Spaniards to achieve his goals was also marked in the speech in December 1976:

When we ask you to go to the polls tomorrow ... it is not for the sake of winning a battle that we have not initiated. It is only because we believe that no one, except the people as a whole, owner of its destiny, has the authority to drive change.

Similarly, he had faith in people's will to achieve change, emphasizing the courage of Spaniards: 'the same people, whose capacities for living together is distrusted, have shown serenity for almost four hundred exciting days, despite sacrifices and distress.' And this same idea was repeated on the last day of the 1977 election campaign: 'I am not appealing to you for comfort, but for effort and hard work to make a better Spain. We are going to bear sacrifices, this is the truth. But we are going to bear them together, without a single exception.'

9. Discourse at TVE, December 14, 1976, during the referendum on the Law of Political Reform that was to be held several days later.

10. First speech as Prime Minister, broadcast by TVE on July 6, 1976.

11. First speech as Prime Minister, broadcast by TVE on July 6, 1976. 
Therefore, together and making a special effort, they could resolve all the problems arising in the transition process. Finally, it was going to be a worthwhile effort.

Suárez involved his followers in his actions throughout his years in political power, but through representation. This empowerment is also shown in that December 1976 speech: 'We want the Spanish people to control and direct the destiny of our country through their freely and democratically elected representatives.'

4. References to the leader's similarity to and identification with his followers. Suárez tried to present himself as one of the Spaniards in most speeches, sharing the same problems. He used this tool in his first speech:

If Spaniards are worried about finding a suitable job or about an increase of unemployment, I am worried too. If they are worried, despite all the statistical explanations, about for example prices rising, I am worried too. If they are worried about not finding a suitable school for the education of their children, I am worried too. ${ }^{12}$

Suárez also stated that 'the nation's concerns are my concerns,' making it clear that he was not going to ignore the problems of common people. He reinforced this idea in the 1977 election campaign, when he said: 'The candidate who speaks to you comes from the rural areas and knows the rural hardship ... I am a normal person' who would govern or would try to govern in a normal way. However, the allusions to his personal biography did not appear more frequently, because Suárez was ultimately a professional politician, who had devoted his entire life to politics, a fact that undoubtedly distanced him from the rest of Spaniards.

5. References to a better future. References to a better future are found in most of his speeches. Sentences such as 'Let us have confidence in ourselves, without fear of the future,' or 'The goal is very specific: future governments will be the result of the free Spanish general will,' already expressed such ideas in his first speech. This speech ended with a clear proposal: 'With this illusion, I invite you to begin together a journey to the future.' A future, in short, that would be built by all Spaniards: 'The government ... hopes to find the support of most of the people to achieve the result that all citizens can walk forward, not only without being injured, but with their heads held high and their consciences clear.' 13

Confidence in a better future went hand-in-hand with fulfilled promises. For that reason, Suárez made an effort to transmit the idea that his government was carrying out the measures announced a few months before. When he participated in the first democratic elections, he communicated this idea: 'We promised to normalize our political life ... and we believe that, with logical deficiencies, we succeeded.' 14 This speech stood out for the showing of his hope in a better future through a communicative strategy: 'I can promise and I do promise' (Puedo prometer y prometo). The phrase was used seven times, and was etched into collective memory, affording great support for the UCS's candidate. But such a phrase was also used later by his political adversaries to remember the broken promises. Among the promises mentioned, we emphasize:

I can promise, and I do promise, that our government's acts will constitute a staggered set of rational and objective measures ... . I can promise and I do promise to

12. First speech as Prime Minister, broadcast by TVE on July 6, 1976.

13. Discourse at TVE, December 14, 1976, during the referendum on the Law of Political Reform, that was to be held several days later.

14. Speech on June 13, 1977, a TVE recording on the last day of the 1977 electoral campaign. 
try to pass a Constitution with all groups represented in Parliament ... . I can promise and I do promise ... to devote all efforts to achieving an understanding among all Spaniards ... . I can promise and I do promise, I will work with honesty.

\subsection{Felipe González: the power of change}

When the Transition began, Felipe González was a stranger to the Spaniards. He led the Partido Socialista Obrero Español (PSOE - the Spanish Socialist Workers' Party) just a year before Franco's death, and until then, he could not appear in public, because of the repression of the dictatorship. Thus, González had to make an effort to be known among citizens in record time. To do that, he received the support of European and American leaders, who appeared at his side at key moments. The great opportunity to present himself to Spanish society occurred in December 1976, at the XXVII PSOE Congress, the first held in Spain since the beginning of the Civil War. His presence in the media started to grow, being recognized by many Spaniards. The first test of his leadership was in the 1977 elections. The PSOE was the second political force, improving its results in the next elections. On both occasions, he participated actively, being the image of his party. During campaign events, several journalists accompanied him, checking the 'irresistible rise' of the socialist leader, as well as the emotion caused by his words. ${ }^{15}$ But he consolidated his leadership after the 1979 election, in the extraordinary PSOE Congress, celebrated on September 1979. On that occasion González achieved the party's rejection of Marxism, overcoming the opposition of many members, in what González thought was an action called to break the PSOE's electoral 'glass ceiling.' With a transformed party, the socialist leader used the idea of change in all his speeches. In the 1982 electoral campaign, Felipe González maintained that change was possible with the PSOE, with him, presenting a credible program for the democratization, modernization, and Europeanization of Spain (Ortega-Ruiz 2012). In some of these events his speech turned into a dialogue with the audience, involving them directly with the socialist program (Palomares 2006, p. 238). According to that, he asked the audience some questions about their problems, their wishes, and their dreams: 'What do we construct?' or 'Which are your main priorities?' These questions were repeated throughout the electoral campaign.

The discourses analysed below are primarily electoral speeches, ${ }^{16}$ although we have also selected the pronouncement given during his first public event in Spain in the XXVII Congress, as well as a speech given at the Parliament when he presented a confidence motion on May 28, 1980. This discourse was intended for the public, because he wanted to be considered as a statesman, prepared to govern, despite the fact that the audience was limited to deputies. Finally, we have analysed an opinion article he wrote close to the 1982 elections, published in El País. Although it is not an oral discourse, we consider that it gathers his fundamental ideas, as well as reaching a significant number of people, given that it was published in the highest-circulation newspaper at that time. ${ }^{17}$

15. This was reflected in newspaper reports as 'Huracán Felipe' (Hurricane Felipe), published in the magazine Cambio 16, on June 12, 1977.

16. He participated in more than 50 meetings in each of the electoral campaigns (1977, 1979, 1982).

17. These data are certified by Oficina de Justificación de la Difusión (Justification of Dissemination Office), an organization for information and control of the print media in Spain. 
1. References to collective history and to the continuity between the past and the present, and even the future. Unlike the UCD, the PSOE had a long history. It was founded in 1879, and was a relevant party in the early twentieth century. In this way, Felipe González turned to the figure of the PSOE's founder, Pablo Iglesias, and other individuals associated with the PSOE, to strengthen the democratic image of his party. Politicians such as Indalecio Prieto or Fernando de los Ríos, who had struggled for democracy in the past, appeared frequently in González's speeches. Similarly, he appealed to the history of Spanish Socialists to link the PSOE with Spain and strengthen the PSOE's position among the citizens. That was made clear in his first political meeting: 'The last Socialist Congress held in Spain was in $1932 \ldots$. . Our party assumes its long history.' Felipe González intended to emphasize the importance of the PSOE in the Spanish political system, unlike formations that were created during the Transition, as the UCD or the right-wing party, Alianza Popular (AP), and showed a history marked by a series of achievements. According to this, he linked the past with the future of the PSOE:

We are sure that after tomorrow the Socialist Party will again be what it has always been in its history and what it will be for many more years of history ... . PSOE has the ability to offer not only the testimony of a history full of honesty ... but the future of honest management of public service for all citizens. ${ }^{18}$

Similarly, he appealed to the history of our country to discredit political opponents from the right wing, blamed for Spain's backwardness as their goals were motivated by the 'selfishness' and the 'complete lack of sense of state' that had historically characterized the Spanish right, which had always looked after their own interests rather than those of the nation. Linked to this accusation, Felipe González strengthened his democratic image to highlight their struggle for democracy in the past, while other politicians were involved in the Franco regime: 'I just have to say that I was not involved at any time in the old regime and I have fought with all my strength for Spain to become a democracy.' ${ }^{19}$

2. References to the community and to collective identity. References to the past and history of the country and the party are also related to the appeal to collective identity. A common history forms the idea of belonging to a community. Thus, Felipe González exhibited at the 1977 election campaign:

There is a people tired of walking in darkness, a people who will decide their future after tomorrow .... PSOE has a commitment we have learned to do with the people, among the people, and for the people of our ancestors, as a family heritage .... We can form a government to serve the people, not a people to serve a government and the interest of a minority.

All the citizens of Spain had in their hands the possibility of changing their history. Felipe González joined the idea of people, also, with values such as freedom, equality, and fraternity. But the idea of a common people, of a community, was complicated by the situation in Spain during the Transition. In the collective memory it still remained the image of a society divided into two blocs, as during the Civil War. For this reason, the socialist leader said that the first task of the socialist government would be to 'nationalize the State,' that is, link all citizens

18. Speech in the final campaign recorded by TVE and broadcast on June 13, 1977, two days before the first democratic elections.

19. Speech in the Basque Country during the electoral campaign, in October 1982. 
to the project called Spain. According to that, change was 'a national goal above the opinions of each one about a given measure. ${ }^{20}$

3. References to the efficacy of collective effort. To carry out his objectives, Felipe González transmitted the idea that he had confidence in the Spanish people and their efforts. Thus, he appealed to the unity of the Spaniards to achieve the final goal: the transformation of Spain. This was reflected in the 1977 electoral campaign:

We want to change society, and we want to change it at the rhythm marked by the people ... . We want to remove the foundations of injustice and we can do it. We can do it with the conscious effort of all citizens. And we are going to make it ... . We know that the work has just begun. ${ }^{21}$

The effort should be maintained to overcome the institutional crisis in the early 1980 s, because this crisis would only be resolved through an "effort of understanding and solidarity among all citizens and sectors of society. ${ }^{22}$ And a similar reference to effort was also used during the 1982 electoral campaign, when he said that the functioning of Spain depended 'on the will not only of the Socialist Party, but of the whole people.'

The whole society was asked to support the change project, and González trusted in the Spaniards to provide this support. The socialist leader showed his confidence in his followers' efforts on many occasions. Thus, in the same speech at the end of the 1977 electoral campaign, he appealed to the intelligence of his followers: 'We know that your vote will be a conscious vote, an effective vote .... We know that you have understood our great message.' He did not consider Spaniards as children, but as a responsible people, prepared to understand the complexity of the political processes in which they were immersed. ${ }^{23}$

4. References to the leader's similarity to and identification with his followers. Since his first appearance, Felipe González was portrayed as a citizen, a citizen who fought for democracy, like the majority of Spaniards. For this reason, in his speeches he used the first person plural, establishing himself next to his followers. But it was not only he who belonged to the people, so did the party:

Again we have the great experience of contact between the Socialist party and the Spanish people, and of contact between the Spanish people and the Socialist party ... . Our party is a party of the people, for the people and it is born from the people. ${ }^{24}$

And to reinforce this idea, he appealed to history, as we reflected above. So, when the socialist victory was taken for granted in 1982, he mentioned: 'I want to stay friends with those who fought against the dictatorship, all from the same trench, around the years 1971 and 1972.'

5. References to the better future. Undoubtedly, the references to a better future are constantly repeated in all his interventions. A new democratic, modern, and European Spain was projected in his speeches and, finally, was supported in

20. Opinion article written by Felipe González and published in El País on October 8, 1982.

21. Speech in the final campaign recorded by TVE and broadcast on June 13, 1977, two days before the first democratic elections.

22. Speech on May 28, 1980, during the censure motion session at Congreso de los Diputados.

23. Opinion article written by Felipe González and published in El País on October 8, 1982.

24. Speech in the final campaign recorded by TVE and broadcast on June 13, 1977, two days before the first democratic elections. 
the 1982 elections. Also, his project, which inspired hope among many citizens, was not a utopia but a realistic vision. For this reason, people had confidence in it. According to that, Felipe González said:

We don't want the Spanish people to believe in unreal illusions ... . We will not be able to solve all the problems at the same time, but we will establish the fundamental bases to do that .... Time for change has come. At this point no one believes the lies and false promises. ${ }^{25}$

A project of a credible society, this was the message that Felipe González communicated in all his speeches. The first time that Spaniards voted after Francoism, the socialist leader transmitted the idea of achieving a 'fairer, freer and more equal society. ${ }^{26}$ In the final speech of the 1977 electoral campaign, González left the destiny of Spain in citizens' hands: 'The future of this country does not depend on a great party, but depends on all citizens.' And that idea did not disappear in his oratory, reappearing in 1982 linked with a message for the future based on the effectiveness of change: 'Change is to make Spain work, that the Administration is not paralysed, that society works, to make a more equal and fairer society.' 27 Felipe González ended his 1982 campaign with the hope of a better future:

If there is a past that was theirs, the future is ours ... . The future belongs to the majority who want change. Go ahead. Conquer the future in peace. Conquer it in freedom. Leave our children a better Spain, with the efforts of everyone. Go ahead and win. Spain and the future are ours.

In this speech, he made clear that the future would be built by all of us, not just by him or by the socialists. And that future was based on freedom, on a new Spain.

\section{COMPARISON BETWEEN ADOLFO SUÁREZ'S AND FELIPE GONZÁLEZ'S DISCOURSES}

During the first period of the Transition - the so-called 'Institutional Transition' Suárez and González obtained the best electoral results, mobilizing a great number of citizens to support their projects. However, when the Constitution was approved and the second democratic elections were held, Adolfo Suárez presented a much more pragmatic discourse without resorting to feelings or high expectations. In fact, during the campaign he said repeatedly, unlike his closest rival - the Socialist Party's presidential candidate - that he defended a 'concrete' program, with no regard to promises that could not be fulfilled. Also, in a letter to the voters published in various media,Suárez stated: 'The UCD has ... a detailed and coherent program, especially concerning unemployment and economic issues, through which we think we can address effectively the solutions now demanded by our people. ${ }^{28}$ Suárez decided not make great promises, being aware that the time for change had concluded with

25. Interview made by TVE on September 29, 1982.

26. Speech in the final campaign recorded by TVE and broadcast on June 13, 1977, two days before the first democratic elections.

27. Interview made by TVE on September 29, 1982.

28. Letter published in several media on February 23, 1979, during the 1979 electoral campaign. 
the proclamation of the Constitution. From his point of view, it was the moment to offer specific measures to win public support. Nevertheless, despite the achievements of recent years, the position for most Spaniards remained precarious given the economic and social crisis, a situation that was reflected in a generalized feeling of disappointment ('desencanto'). This change in the public mood partially explains why, in the 1979 elections, the turnout dropped significantly, by about 10 per cent. From that moment, the PSOE's voting intentions grew up progressively and a more exciting speech, as we are going to discuss below, started to gain greater support among citizens in the early 1980s. Following the terminology of Linz, we can consider Suárez as an innovative leader. This kind of leader is a risk-taker, standing out for making determinant decisions to drive the political process towards the desired horizon (Linz 2001, p. 90). But, according to the former Yale professor, innovative leaders fail when they try to take advantage of their past achievements to stay in powerful positions, finally being removed from government. This is exactly what happened to Suárez, who resigned as President and as the UCD's leader in February 1981, as a consequence -among other reasons - of the extraordinary pressure exerted on him from the majority of his own backbenchers. For the next election, he participated by heading a new party, Centro Social y Democrático (CDS), which did not get a good result, in spite of the fact that Adolfo Suárez was still popular among Spaniards.

In contrast to Suárez's fall, Felipe González increased his popular support. He maintained his discourses of change, motivating his followers with his ideas about a better future. His promises were credible because he appeared as a person who shared with his fellow citizens their worries and concerns, as well with their wishes for a new society, a new country. The 1982 electoral campaign ended with a massive party meeting. Felipe González had left behind thousands of miles of road, a journey across Spanish geography along which he could explain his great future project. During the campaign he presented concrete promises, which could be considered as pragmatic elements or transactional measures; that is, tangible rewards. Thus, the PSOE's leader promised to create 800,000 jobs, 400,000 houses per year, the restructuring of the banking system, and price control of basic goods. However, these measures were all proposed under the umbrella of change. Felipe González won the elections with an exciting message of change, mentioning only in passing those concrete proposals. Thus, citizens did not vote PSOE in return for promises of job creation or house building, but in return for the promise of change.

\section{CONCLUSIONS}

Throughout this study, we have made a first qualitative approach to the discourses displayed in the Spanish Transition to democracy. During this period, Adolfo Suárez and Felipe González tried to gain supporters for their respective visions of the future, but only one of them was consistently successful in undertaking such a challenge. As we have seen, that had much to do with Felipe González's ability to connect with his followers, appealing to a collective history, identity, and effort, as well as making references to his similarities with them, and envisioning a promising image of a better future.

To identify those communication strategies we used, essentially, the analysis scheme conceived by Shamir et al. on the motivational effects of leadership. Given that appealing to collective identity, common effort, empowerment of followers, and an exciting future has a greater positive impact than only referring to transactional measures, we intended to prove the importance of the former discourses (based on the fostering of 
followers' self-concept) for the building of a solid leadership process in Spain, during a period featuring the widely spread perception of crisis and transformation.

Ultimately, this study is a first approach to the discourses of change in Spain. We are going to continue analysing the discourses of the new parties that have great popular support in Southern European countries such as Spain. Also, we aim to carry out a quantitative analysis to check how often leaders mention the words included in the categories used in the present study. Nowadays, the Spanish political situation provides a great opportunity to analyse the discourses of change in a crisis context, especially given that, in this atmosphere of discontent, new parties have burst into political scene. However, we consider it preferable to wait until the next electoral campaign - in November 2015 - to verify whether the new parties use these communication elements to gain electoral support.

\section{REFERENCES}

Antonakis, J. (2012): 'Transformational and Charismatic Leadership,' in D.V. Day and J. Antonakis (eds), The Nature of Leadership, Thousand Oaks, CA: Sage, pp. 3-34.

Bandura, A. (1986): Social Foundations of Thought and Action: A Social Cognitive Theory, Englewood Cliffs, NJ: Prentice-Hall.

Bass, B. (1998): Transformational Leadership: Industrial, Military and Educational Impact, Mahwah: Lawrence Erlbaum Associates.

Billing, Michael (2004): Banal Nationalism, London: Sage.

Blondel, J. (1987): Political Leadership: Toward a General Analysis, London: Sage.

Bong, M. and R.E. Clark (1999): 'Comparison between Self-Concept and Self-Efficacy in Academic Motivation Research,' Educational Psychologist, 34(3), 139-153.

Burns, J.M. (1978): Leadership, New York: Harper and Row.

Burns, J.M. (2003): Transforming Leadership, London: Atlantic.

Burns, R.B. (1990): El Autoconcepto: Teoría, Medición, Desarrollo y Comportamiento, Bilbao: Ega.

Caciagli, M. (1986): Elecciones y Partidos en la Transición Española, Madrid: Centro de Investigaciones Sociológicas.

Charteris-Black, J. (2004): Corpus Approaches to Critical Metaphor Analysis, Basingstoke, UK and New York: Palgrave Macmillan.

Charteris-Black, J. (2007): The Communication of Leadership: The Design of Leadership Style, London and New York: Routledge.

Charteris-Black, J. (2012): 'Comparative Keyword Analysis and Leadership Communication: Tony Blair. A Study of Rhetorical Style,' in L. Helms (ed.), Comparative Political Leadership, Basingstoke, UK: Palgrave Macmillan, pp. 142-164.

Chouliaraki, L. and N. Fairclough (1999): Discourse in Late Modernity: Rethinking Critical Discourse Analysis, Edinburgh, UK: Edinburgh University Press.

Cotarelo, R. (1992): 'Introducción: La Transición Democrática Española,' in R. Cotarelo (ed.), Transición Política y Consolidación Democrática. España (1975-1986), Madrid: Centro de Investigaciones Sociológicas, pp. 1-16.

Davis, K.M. and W.L. Gardner (2012): 'Charisma Under Crisis Revisited: Presidential Leadership, Perceived Leader Effectiveness, and Contextual Influences,' The Leadership Quarterly, 23(5), 918-933.

Elcock, H.J. (2001): Political Leadership, Cheltenham, UK and Northampton, MA: Edward Elgar. Flowerdew, John (2014): 'Introduction: Discourse in Context,' in J. Flowerdew (ed.), Discourse in Context: Contemporary Applied Linguistics, London and New York: Bloomsbury, pp. 1-18.

Foucault, M. (1972): The Archaeology of Knowledge, New York: Pantheon Books.

Gecas, V. (1982): 'The Self Concept,' Annual Review of Sociology, 8, 1-33.

Goatley, A. (1997): The Language of Metaphors, London: Routledge. 
132 Leadership and the Humanities, Vol. 3 No. 2

Gunther, R., P.N. Diamandouros, and H.-J. Puhle (1995): The Politics of Democratic Consolidation: Southern Europe in Comparative Perspective, Baltimore, MD: The Johns Hopkins University Press.

House, R.J. and B. Shamir (1993): 'Toward the Integration of Transformational, Charismatic and Visionary Theories,' in M.M. Chemers and R. Ayman (eds), Leadership Theory and Research: Perspectives and Directions, San Diego, CA: Academic Press, pp. 81-107.

Lessa, I. (2006): 'Discursive Struggles Within Social Welfare: Restaging Teen Motherhood,' British Journal of Social Work, 36, 283-298.

Linz, J.J. (2001): 'El Liderazgo Innovador en la Transición a la Democracia y en una Nueva Democracia,' in M. Alcántara and A. Martínez (eds), Política y Gobierno en España, Valencia: Tirant lo Blanch, pp. 57-98.

Markus, H. and P. Nurius (1986): 'Possible Selves,' American Psychologist, 41, 954-969.

Masciulli, J., M.A. Molchanov, and W.A. Knight (2009): 'Political Leadership in Context,' in J. Masciulli, M.A. Molchanov, and W.A. Knight (eds), The Ashgate Research Companion to Political Leadership, Farnham, UK: Ashgate, pp. 3-27.

McAllister, I. (1996): 'Leaders,' in L. Leduc, R. Niemi, and P. Norris (eds), Comparing Democracies: Elections and Voting in Global Perspective, Thousand Oaks, CA: Sage, pp. 278-296.

McAllister, I. (2007): 'The Personalization of Politics,' in R.J. Dalton and H.-D. Klingemann (eds), The Oxford Handbook of Political Behavior, Oxford: Oxford University Press, pp. 571-588.

O'Brien, T.A. (2007): 'The Role of the Transitional Leader: A Comparative Analysis of Adolfo Suárez and Boris Yeltsin,' Leadership, 3(4), 419-432.

Ortega-Ruiz, M. (2012): La Sociedad Imaginada: La Visión de Futuro de los Líderes en Períodos de Cambio Político, Granada: Universidad de Granada.

Pajares, F. (1996): 'Self-efficacy Beliefs in Academic Settings,' Review of Educational Research, 66, 543-578.

Palomares, A. (2006): Felipe González: El hombre y el politico, Barcelona: Ediciones B.

Shamir, B., M.B. Arthur, and R.J. House (1993): 'The Motivational Effects of Charismatic Leadership: A Self-Concept Based Theory,' Organization Science, 4(4), 577-594.

Shamir, B., M.B. Arthur, and R.J. House (1994): 'The Rhetoric of Charismatic Leadership: A Theoretical Extension, a Case Study, and Implications for Research,' Leadership Quarterly, $5(1), 25-42$.

Weber, M. (1993): Economía y Sociedad, Madrid: Fondo de Cultura Económica.

Wodak, Ruth and Michael Meyer (2009): 'Critical Discourse Analysis: History, Agenda, Theory and Methodology,' in R. Wodak and M. Meyer (eds), Methods of Critical Discourse Analysis, London: Sage, pp. 1-33.

Zúquete, J.P. (2011): 'The Flight of the Eagle: The Charismatic Leadership of Sá Carneiro in Portugal's Transition to Democracy,' Leadership Quarterly, 22(2), 295-306. 